\title{
New records of Holocene polar bear and walrus (Carnivora) in the Russian Arctic
}

\author{
Gennady G. Boeskorov*, Alexey N. Tikhonov, Albert V. Protopopov, \\ Alexander D. Stepanov, Valery V. Plotnikov, Johannes van der Plicht, \\ Marina V. Shchelchkova \& Gennady F. Baryshnikov
}

ABSTRACT. This article discusses recent finds of Holocene polar bear and walrus from the northern regions of Russia. The ulna of a polar bear was found on Vaygach Island and radiocarbon dated to $1,971 \pm 25$ $\mathrm{BP}$ (OxA-23631). This calibrates to 430-540 AD, taking into account the marine reservoir effect. The size of the bone is similar to that of a recent Ursus maritimus. The locality of the fossil bone is within the modern species range, which developed about two millennia ago. In 2014 a walrus tusk was found on the coast of New Siberia Island and is radiocarbon dated to 5,065 \pm 35 BP (GrA-62452). This calibrates to 3,510-3,370 $\mathrm{BC}$, taking into account the marine reservoir effect. Its size and morphology are identical to that of an adult male of the subspecies Odobenus rosmarus laptevi. This subspecies populates the eastern parts of the Kara Sea, the entire Laptev Sea and the western parts of the East Siberian Sea. This new discovery could mean that populations of $O$. rosmarus laptevi inhabited the waters near the New Siberian Islands during the Middle Holocene, and that the present-day coastline of the Siberian Arctic Islands was already formed at that time.

How to cite this article: Boeskorov G.G., Tikhonov A.N., Protopopov A.V., Stepanov A.D., Plotnikov V.V., van der Plicht J., Shchelchkova M.V., Baryshnikov G.F. 2018. New records of Holocene polar bear and walrus (Carnivora) in the Russian Arctic// Russian J. Theriol. Vol.17. No.2. P.68-77. doi: 10.15298/ rusjtheriol.17.2.02

KEY-WORDS: Ursus maritimus, Odobenus rosmarus, Holocene, Arctic, Russia.

Gennady G. Boeskorov [gboeskorov@mail.ru], Diamond and Precious Metals Geology Institute, Siberian Branch of Russian Academy of Sciences, Prospect Lenina 39, Yakutsk 677980, Russia; Alexey N. Tikhonov [atikh@mail.ru], Zoological Institute, Russian Academy of Sciences, Universitetskaya nab. 1, Saint Petersburg 199034, Russia; Albert V.Protopopov [a.protopopov@mail.ru], Mammoth Fauna study Department, Yakutia Academy of Sciences, Prospect Lenina 39, Yakutsk 677007, Russia; Alexander D. Stepanov [a.d.step@yandex.ru], M.K. Ammosov's NorthEastern Federal University, Museum of Archaelogy and Ethnography, Kulakovskogo str. 48, Yakutsk 677013, Russia; Valery V. Plotnikov [mammuthus@mail.ru], Mammoth Fauna study Department, Yakutia Academy of Sciences, Prospect Lenina 39, Yakutsk 677007, Russia; Johannes van der Plicht [j.van.der.plicht@rug.nl], Center for Isotope Research, Groningen University, Nijenborgh 6, 9747 AG Groningen, The Netherlands; Marina V. Shchelchkova [mar-shchelchkova@yandex.ru], M.K. Ammosov's North-Eastern Federal University, Natural Sciences Institute, Kulakovskogo str. 48, Yakutsk 677013, Russia; Gennady F. Baryshnikov [G_Baryshnikov@mail.ru], Zoological Institute, Russian Academy of Sciences, Universitetskaya nab. 1, Saint Petersburg 199034, Russia.

\section{Новые голоценовые находки белого медведя и моржа (Carnivora) на севере России}

\section{Г.Г. Боескоров*, А.Н. Тихонов, А.В. Протопопов, А.Д. Степанов, В.В. Плотников, Й. ван дер Плихт, М.В. Щелчкова, Г.Ф. Барышников}

РЕЗЮМЕ. Статья содержит описание новых голоценовых находок белого медведя и моржа из северных регионов России. Локтевая кость белого медведя обнаружена на о-ве Вайгач и имеет радиоуглеродную дату 1,971 25 лет назад (ОхА-23631). Эта дата калибруется в 430-540 лет нашей эры, учитывая морской резервуарный эффект. По размерам и строению она сходна с костью ныне живущего Ursus maritimus. Находка сделана в пределах современного видового ареала, который, вероятно, сформировался в начале нашей эры. Клык моржа был найден в 2014 г. на побережье о-ва Новая Сибирь (Новосибирские о-ва) и датирован средним голоценом: 5,065 35 л.н. (GR-62452). C учетом резервуарного эффекта, калиброванный возраст этой находки - 3,510-3,370 лет до нашей эры. По морфологии клык с о-ва Новая Сибирь идентичен клыку современного самца подвида 
Odobenus rosmarus laptevi. Этот подвид распространен в восточной части Карского моря, по всему морю Лаптевых и в западной части Восточно-Сибирского моря. Новая находка доказывает, что популяции O. rosmarus laptevi обитали в водах около о-ва Новая Сибирь в течение среднего голоцена и что в это время уже сформировалась современная береговая линия островов Сибирской Арктики.

КЛЮЧЕВЫЕ СЛОВА: Ursus maritimus, Odobenus rosmarus, голоцен, Арктика, Россия.

\section{Introduction}

Pleistocene finds of marine mammals in the Arctic Basin are quite rare considering that during the Ice Age dry land stretched further north, including regions of the contemporary oceanic shelf. Far northern Upper Paleolithic sites as Berelekh and Yanskaya in Yakutia (Russian Federation) do not contain any pinniped and polar bear bones, including those of walruses (Mochanov, 1977; Pitulko \& Pavlova, 2010). At the end of the Pleistocene these sites were located far away from the seashore. Holocene bone remains of whales, pinnipeds and polar bears can provide us with crucial information about the polar water areas during prehistory, when marine transgression resulted in the gradual development of the present-day coastline and ranges of northern marine mammal species.

\section{Material and Methods}

The right ulna bone (ZIN 36421) of a polar bear from the Vaygach Island was measured using the methodology of von den Driesch (1976). It was compared with ulna bones of the modern polar bear from Svalbard Island (ZIN 30965) and Late Pleistocene one found near the mouth of Mordy-Yakhk River at the western shore of Yamal Peninsula (ZIN 25659). This territory of Yamal was the place of findings of Pleistocene bones of Odobenus rosmarus (Linnaeus, 1758), Mammuthus primigenius (Blumenbach, 1799), Coelodonta antiquitatis (Blumenbach, 1799), Equus ferus Boddaert, 1785, Rangifer tarandus (Linnaeus, 1758), Delphinapterus leucas (Pallas, 1776) and other whales (Vereshchagin, 1969). In the opinion by Vereshchagin, the type of preservation and fossilization of this polar bear ulna is similar to those of mammoth and rhino bones. He also notes that, according to the records of geologists, fossil bones were collected in this region on the slopes and at foots of outcrops formed by boreal transgression deposits, overlaid by sediments of the last glaciation as well as by postglacial lacustrine and peat bog deposits.

In the scientific literature, two or three variables are commonly measured for walrus tusks: the length of each tusk on its outer curve from the farthest point of the alveolus to the tip, the sagittal diameter near the entrance of the alveolus, and the circumference of the tusk at its base (Ognev, 1935; Chapsky, 1963; Heptner et al., 1976; Sokolov, 2001). For a more accurate comparison we used additional variables developed for tusks of the woolly mammoth (Mammuthus primigenius) (Vereshchagin \& Tikhonov, 1987; Tab. 3). Nine- teen tusks of adult male Odobenus rosmarus were measured in the collection of ZIN .

It has been speculated that the subfossil walrus tusk from the New Siberia Island served as a tool for humans. Therefore it has been inspected for traces of wear by trace evidence analysis (Semenov, 1957).

Radiocarbon analysis of the ulna bone of a polar bear from the Vaygach Island was carried out by the University of Oxford, United Kingdom, and of the walrus tusk from the New Siberia Island by the University of Groningen, the Netherlands. Both laboratories use AMS (Accelerator Mass Spectrometry) for measurements of the ${ }^{14} \mathrm{C}$ concentration. The radiocarbon dates are calculated and reported by convention in BP (Mook \& van der Plicht, 1999). They require calibration in order to obtain absolute (calendar) dates. This is done using the calibration curve IntCal13 (Reimer et al., 2013), taking into account the marine reservoir effect. Marine fauna shows an offset of 400 years relative to terrestrial organisms. This also applies to mammals (including polar bear and walrus) feeding on marine food resources (Tauber, 1979).

Institutional abbreviations: ZIN - Zoological Institute, Russian Academy of Sciences, St. Petersburg, Russia.

Radiocarbon dating terminology abbreviations: $\mathrm{BP}-{ }^{14} \mathrm{C}$ years before present; calBP — calibrated ${ }^{14} \mathrm{C}$ dates (relative to AD 1950); AD - Anno Domini; BC before Christ; BP — before Present; OxA - laboratory code of the University of Oxford, United Kingdom; GrA - laboratory code of the University of Groningen, the Netherlands; LU - laboratory code of the Leningrad (now St. Petersburg) University.

\section{Results}

Polar bear (Ursus maritimus Phipps, 1774). In 2010 on the western coastline of Vaygach Island, the Arkhangelsk Region of Russia, V. Sentyabov found a polar bear ulna bone with damaged distal end (ZIN 36421) (Fig. 1). It was found on a sea cliff at a distance of $150 \mathrm{~m}$ from the ancient Nenets people shrine, which contained the seven-faced idol. However, this polar bear bone does not seem to be connected to the shrine in any way and looks more ancient. Ceremonial sacrificial altars of the Nenets people are found in abundance from the White Sea coasts in the west to the Yenisei River in the east. There were many altars on the Vaygach Island, and the northern tip of the island was named Bolvansky Nos ("Blockheads Cape") because idols ("bolvans" in Russian, "blockheads" in English) were found regularly. In the past the Nenets people worshiped polar bear 


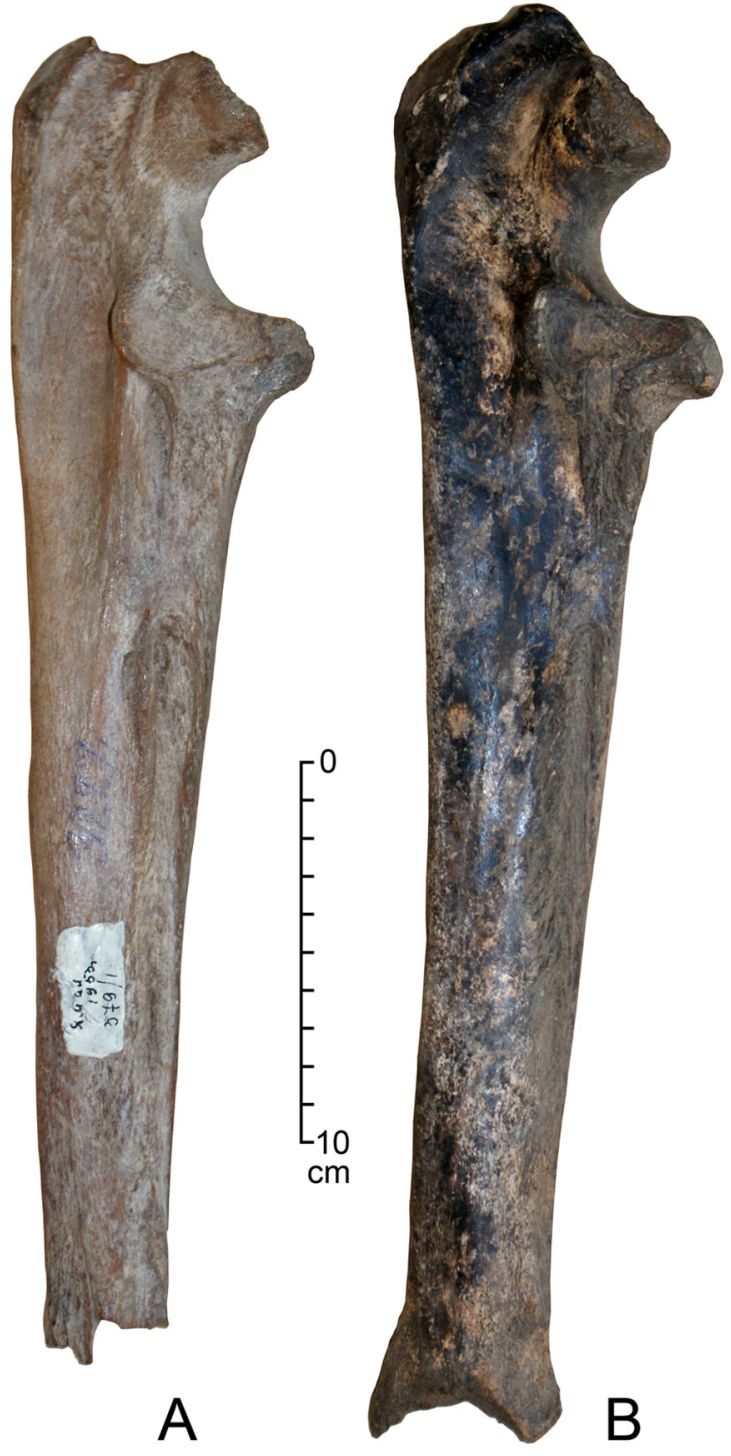

Fig. 1. Ulna bones of the polar bear (Ursus maritimus): A - Mordy-Yakhk River, Yamal Peninsula, Late Pleistocene (ZIN 25659); B - Vaigach Island, Holocene (ZIN 36421).

skulls and frequently placed them on their altars (Uspensky \& Kholodova, 1977). According to historical sources, the Nenets people colonized northern CisUralian areas and the northern parts of Yamal Peninsula not earlier than the $18^{\text {th }}$ century (Tishkov et al.,
2008). The polar bear ulna bone appeared to be much older. It is dated by radiocarbon to $1,971 \pm 25 \mathrm{BP}(\mathrm{OxA}-$ 23631). This calibrates to $430-540 \mathrm{AD}$, taking into account the marine reservoir effect.

Judging by its size and shape, the ulna bone from the Vaygach Island is not much different from modern U. maritimus (Tab. 1). Kurtén (1964) noted that the greatest length of polar bear ulnae for male and female specimens $(n=9)$ varies from 334 to $428 \mathrm{~mm}$, the mean value being $374 \mathrm{~mm}$, which is close to the Vaygach Island bone length. The anterior tubercle on the tuber olecrani has a significant distance from the trochlear notch (incisura semilunaris) which is specific for polar bear. It is the main difference between ulna bones of polar bear and brown bear (U. arctos Linnaeus, 1758) (Gromova, 1950).

Walrus (Odobenus rosmarus (Linnaeus, 1758). In the summer of 2014, a mineralized subfossil walrus tusk was found on the Blagoveshchensky Strait shore on the western coastline of the New Siberia Island (New Siberian Islands Archipelago) (Fig. 2). It was grayish-brown in color with a dented surface and showing a lot of structure, presumably caused by sea waves. The alveolar cone was almost entirely overgrown, indicating that it belonged to an adult or even an old male. Its form is almost straight, which is rare in modern walruses (Figs 2,3). Adult walruses usually have arched tusks (Fig. 3, C-E). Similar shapes were found only in a few specimens among studied ZIN RAS collections (Fig. 3, B).

The sides of the tusk are flattened, which is typical for modern specimens. In addition, the tip part of the tusk is sharpened like a blade at one side, and there are traces similar to transverse grooves in the proximal part of the tusk. It has been speculated that this was done by ancient man in order to use the tusk as a weapon, attaching it to a wooden handle like an ice pick or a spearhead. But there are no similar weapons known among all known artifacts of ancient Arctic peoples, only one "spearhead (or arrow-head) made from walrus tusk" from the Tatyanino Lake site in the Indigirka River delta is mentioned by A.P. Okladnikov (1955: 123).

Game manager Mr. Semen I. Kavry (Wildlife Protection Centre in Chukotka Autonomous Region, Anadyr city), an expert on the culture of native peoples of Chukotka, testified that Chukotka peoples did not have such weapons. At the end of the $2^{\text {nd }}$ millennium $\mathrm{BC}$ to

Table 1. Sizes (in mm) of the polar bear (Ursus maritimus) ulna bones.

\begin{tabular}{|l|c|c|c|}
\hline \multirow{2}{*}{$\begin{array}{l}\text { Measurements (according to } \\
\text { von den Driesch, 1976) }\end{array}$} & $\begin{array}{c}\text { Mordy-Yakhk R., Yamal } \\
\text { Peninsula, Late Pleistocene (?) }\end{array}$ & $\begin{array}{c}\text { Vaygach Island, } \\
\text { Late Holocene }\end{array}$ & $\begin{array}{c}\text { Svalbard } \\
\text { Island, modern }\end{array}$ \\
\cline { 2 - 4 } & ZIN 25659 & ZIN 36421 & ZIN 30965 \\
\hline Greatest length (GL) & $>344$ & $>369$ & 384.6 \\
\hline $\begin{array}{l}\text { Depth across the processus } \\
\text { anconaeus (DPA) }\end{array}$ & $>74.5$ & 773.5 & 77.2 \\
\hline $\begin{array}{l}\text { Greatest width across the } \\
\text { coronoid process (WPC) }\end{array}$ & 63.8 & 62.6 & 70.3 \\
\hline
\end{tabular}




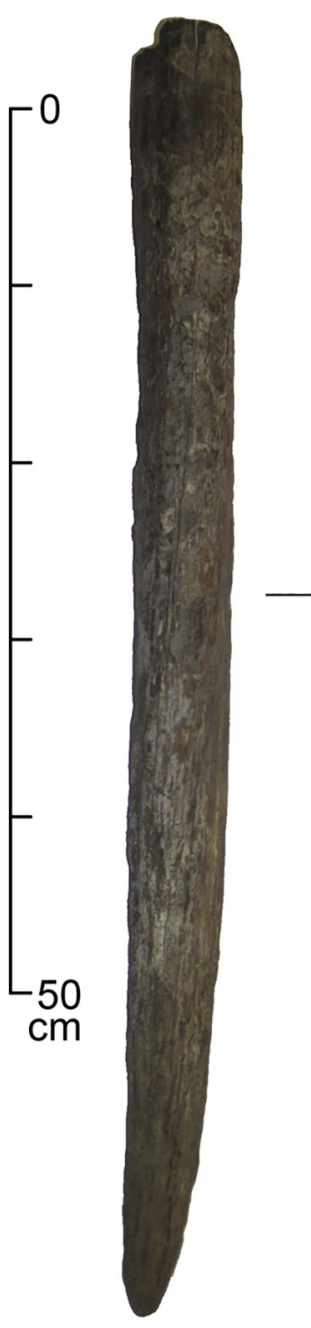

A
B

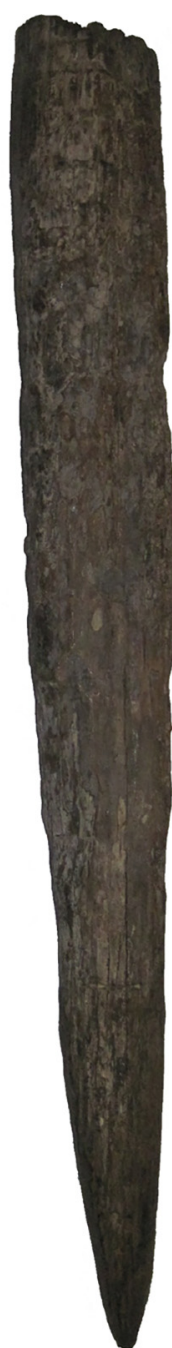

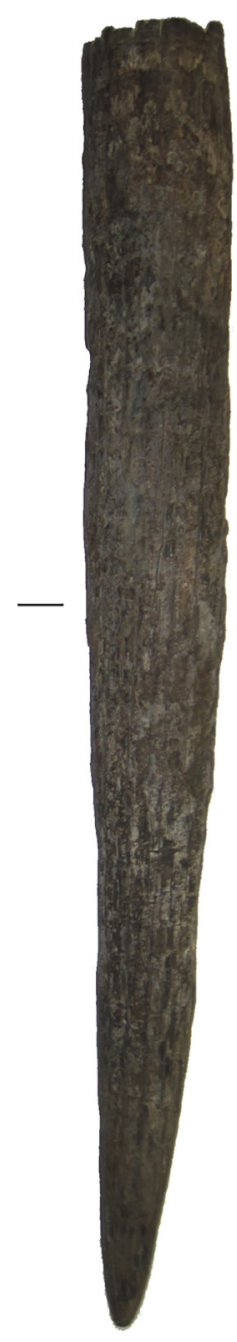

C
Fig. 2. Tusk of the walrus (Odobenus rosmarus) from the New Siberia Island:

A - front view, B - left side view, C - right side view.

$1^{\text {st }}$ millennium AD ancient Chukotka and Kamchatka cultures used fully modified walrus tusks in their handiwork (Dikov, 1974, 1977; Arutyunov \& Sergeev, 1975), but a modified tusk cannot be used for comparison. Trace evidence analysis carried out in Yakutsk showed that a walrus tusk from the New Siberia Island was not a human tool because there are no real traces of artificial treatment, and the proximal part is not modified to be attached to a handle. It is likely that the sharpened tip of the tusk and transverse grooves were not made by man, but were caused by sea ice which often occurs on a shore, also partly being destroyed by sea waves.

The walrus tusk from the New Siberia Island was dated by Radiocarbon to the Mid Holocene in Groningen, the Netherlands. The date is $5,065 \pm 35$ BP (GrA62452 ), which calibrates to $3,510-3,370 \mathrm{BC}$ taking into account the marine reservoir effect (Tab. 2).

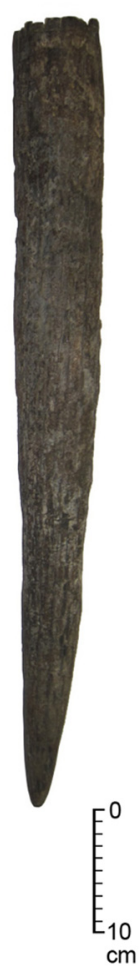

A

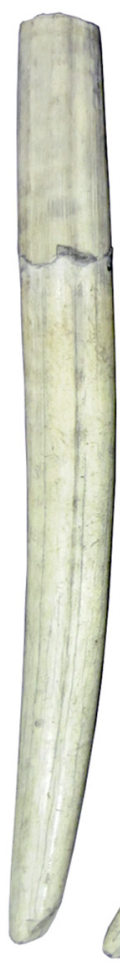

B

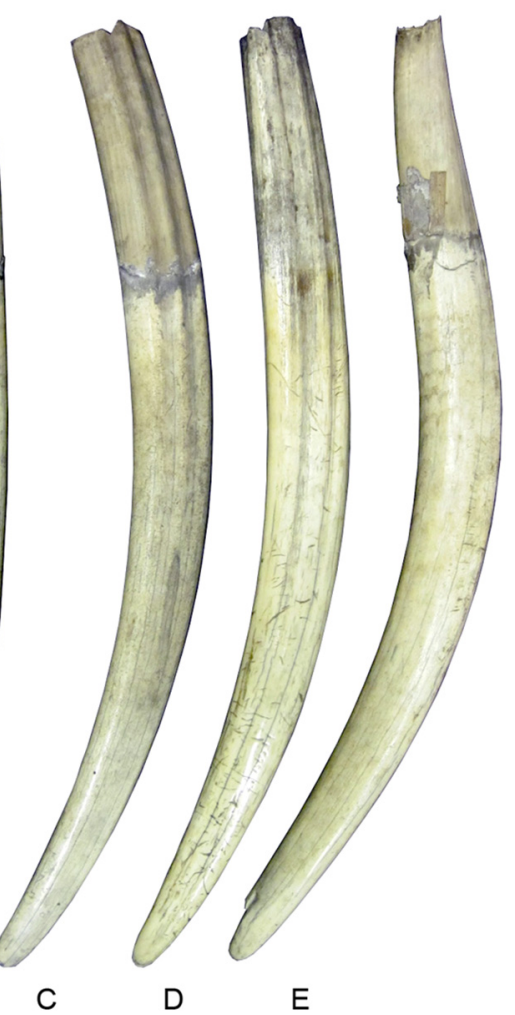

Fig. 3. Tusks of the walrus (Odobenus rosmarus): A - subfossil, New Siberia Island; B-D - modern (collections of ZIN RAS).

Allen (1880) wrote that tusks of the Pacific Ocean walrus (O. rosmarus divergens (Illiger, 1815)) are longer and thicker than the ones of the Atlantic walrus. This was confirmed by Ognev (1935). These facts were used later while describing subspecies differences between walruses (Heptner et al., 1976; Aristov \& Baryshnikov, 2001; Sokolov, 2001). Measuring the modern tusks from the ZIN RAS collection proved this tendency (Tab. 3). It was also observed that the subspecies $O$. rosmarus laptevi Chapsky, 1940 from the Laptev Sea is a bit larger than Atlantic subspecies O. rosmarus rosmarus (Linnaeus, 1758) (Heptner et al., 1976; Aristov $\&$ Baryshnikov, 2001), but our studies showed that $O$. rosmarus laptevi has shorter and thinner tusks than $O$. rosmarus rosmarus (Tab. 3 ).

The size of the tusk from the New Siberia Island is similar to that of present-day $O$. rosmarus laptevi adult males tusks. This subspecies now populates eastern parts of the Kara Sea, the entire Laptev Sea and the western parts of East Siberian Sea (Heptner et al., 1976; Sokolov, 2001). The new subfossil tusk discovery could mean that the $O$. rosmarus laptevi subspecies originated near the New Siberian Islands during the Middle Holocene. The time and place of its origin can possibly be determined by investigating DNA in the near future. 
Table 2. Holocene finds of walrus (Odobenus rosmarus) remains in the north of Siberia.

\begin{tabular}{|c|c|c|c|}
\hline Locality & $\begin{array}{l}\text { Radiocarbon dates (BP) of } \\
\text { bones, or cultural layers }\end{array}$ & $\begin{array}{l}\text { Material used } \\
\text { for dating }\end{array}$ & Source \\
\hline $\begin{array}{l}\text { East Siberian Sea, Zhokhov } \\
\text { Island, Zhokhov site }\end{array}$ & $9,000-7,800$ & cultural layer & $\begin{array}{c}\text { Pitulko \& Kasparov, } \\
\text { 1996; Pitulko, } 1998\end{array}$ \\
\hline $\begin{array}{l}\text { East Siberian Sea, New } \\
\text { Siberia Island }\end{array}$ & $5,065 \pm 35(\mathrm{GrA}-62452)$ & walrus tusk $(\S)$ & This work \\
\hline $\begin{array}{c}\text { The Indigirka River mouth, } \\
\text { Ularovskaya and Tatyanino } \\
\text { lake sites }\end{array}$ & $\begin{array}{c}\text { The sites of the } \\
\text { Ymyakhtakh culture of the } \\
\text { Late Neolithic }(4,000- \\
3,000 \mathrm{BP})\end{array}$ & cultural layer & $\begin{array}{l}\text { Okladnikov \& } \\
\text { Gurvich, } 1957\end{array}$ \\
\hline $\begin{array}{c}\text { Chukchi Sea, Wrangel } \\
\text { Island, settlement Chertov } \\
\text { Ovrag }\end{array}$ & $3,265 \pm 65(\mathrm{Ua}-18085)$ & walrus bone $(\S)$ & $\begin{array}{l}\text { Gerasimov et al., } \\
2004\end{array}$ \\
\hline $\begin{array}{c}\text { Bering Strait, Chukchi } \\
\text { Peninsula, Dezhnevskoe } \\
\text { ancient Eskimo settlement }\end{array}$ & $2,630-2,480$ & cultural layer & Knyazev, 1995 \\
\hline $\begin{array}{l}\text { Bering Strait, coast of the } \\
\text { Chukchi Peninsula, the } \\
\text { ancient Eskimo settlement of } \\
\text { Ekven }\end{array}$ & $\begin{array}{c}2,111 \pm 67 \text { (IEMEA-1027) } \\
\text { (most ancient date } \\
\text { selected) }\end{array}$ & walrus bone $(\S)$ & Dinesman et al., 1996 \\
\hline $\begin{array}{l}\text { Chukchi Sea, the Chukchi } \\
\text { Peninsula, the ancient } \\
\text { Eskimo settlement of } \\
\text { Vankarem }\end{array}$ & $1,250-550$ & cultural layer & $\begin{array}{l}\text { Dikov, 1977; Gorlova } \\
\text { \& Vasyukov, } 2013\end{array}$ \\
\hline
\end{tabular}

$\left(^{*}\right)$ numbers correspond to those in Fig. 3.

$(\S){ }^{14} \mathrm{C}$ date must be corrected for marine reservoir effect (see text).

\section{Discussion}

Fossil and subfossil finds of polar bear are quite rare, probably because of the semi-aquatic lifestyle of polar bears in coastal areas and ice drifting in the circumpolar basin. The vast areas of its former habitat are now deep under the seawater. Nevertheless some of the finds proved that during the Late Pleistocene the range of $U$. maritimus extended further down south in Europe, to the southern regions of Norway, Sweden, Denmark, North Germany (Hamburg), England and Ireland (Aaris-Sørensen \& Petersen, 1984; Berglund et al., 1992; Blystad et al., 1983; Crockford, 2012; Edwards et al., 2011; Erdbrink, 1953; Håkansson, 1976; Kurtén, 1964; Zimmermann, 1845) (Fig. 4, Tab. 4). During the Holocene $U$. maritimus also lived in the Baltic Sea area. A complete glaciation of the Arctic Basin during the Ice Age could explain this expansion to the south (Baryshnikov, 2007).

Other Holocene polar bear finds known from Greenland, the Svalbard Archipelago, Ireland and continental Europa (Kurtén, 1964; Ingólfsson \& Wiig, 2008) show that during the Holocene $U$. maritimus inhabited the whole northern region of the Atlantic Ocean. To this day Holocene finds in northern European Russia are either Medieval or Modern age. The oldest Holocene polar bear fossils were found in the locality Tiutei-Sale-
1 on the western coast of Yamal Peninsula, dating to the $6^{\text {th }}-7^{\text {th }}$ centuries AD (Fedorova et al., 1998; Kosintsev, 2006).

The Vaygach Island find is located within the range of the modern species (Fig. 4), which presumably dates back to about 2,000 years.

Pleistocene walrus fossils have been found in the Eurasia arctic zone on the Yamal Peninsula (MordyYakhk River) together with polar bear and beluga whale (Delphinapterus leucas (Pallas, 1776)) bones (Vereshchagin, 1969). Fragment of a walrus mandibular bone, presumably from the Late Pleistocene, was found on Kotelny Island (ZIN 4838, A.A. Bunge collection, 1886). To this day, this record remains the only one in the Russian Arctic.

During the Late Pleistocene, the range of the walrus in North America moved more to the south, spreading to South Carolina along the Atlantic Coast and to San Francisco along the Pacific Coast. The oldest walrus fossils on the North American coastline were found on Vancouver Island (British Columbia), with the date older than 40,000 years (Harington \& Beard, 1992) and on Herschel Island (North-Western Canada territory), dated to $45,630 \pm 1580 \mathrm{BP}$ (Morlan, 1999).

It is important to point out that walruses lived further south along the European coastline as well. The North Sea floor probably is the richest area in the world for the walrus fossils. Thousands of bone fragments and 
Table 3. The sizes of the adult walrus (Odobenus rosmarus) males tusks.

\begin{tabular}{|c|c|c|c|c|c|}
\hline \multirow{3}{*}{ Measurements, mm } & \multirow{3}{*}{$\begin{array}{c}\text { Subfossil } \\
\\
\text { New } \\
\text { Siberia } \\
\text { Island, the } \\
\text { Laptev Sea }\end{array}$} & \multicolumn{4}{|c|}{ Recent } \\
\hline & & \multirow{2}{*}{$\begin{array}{l}\begin{array}{l}\text { O. rosmarus } \\
\text { rosmarus, } \\
\text { Barents Sea, } \\
\mathrm{n}=4\end{array} \\
\underline{\mathrm{lim}} \\
\mathrm{X} \pm \mathrm{m}\end{array}$} & \multicolumn{2}{|c|}{$\begin{array}{l}\text { O. rosmarus } \\
\text { laptevi, Laptev } \\
\text { Sea }\end{array}$} & \multirow{2}{*}{$\begin{array}{c}\begin{array}{c}\text { O. rosmarus } \\
\text { divergens, } \\
\text { Kamchatka, the } \\
\text { Bering Sea, ZIN, } \\
\mathrm{n}=10 \\
\underline{\mathrm{lim}} \\
\mathrm{X} \pm \mathrm{m}\end{array}\end{array}$} \\
\hline & & & $\underline{\lim }$ & $\mathrm{n}$ & \\
\hline $\begin{array}{l}\text { Full length on its outer curve } \\
\text { from the farthest point of } \\
\text { alveolus to the tip }\end{array}$ & 603 & $\frac{630-801}{712.8 \pm 38.23}$ & $\frac{584-638}{612.3 \pm 15.66}$ & 3 & $\frac{650-880}{767.7 \pm 20.76}$ \\
\hline $\begin{array}{l}\text { Total length of the tusk } \\
\text { along the chord }\end{array}$ & 590 & $\frac{615-762}{688.5 \pm 33.5}$ & $\frac{572-630}{603.3 \pm 16.93}$ & 3 & $\frac{646-816}{733.4 \pm 17.39}$ \\
\hline $\begin{array}{l}\text { Length from the alveolar } \\
\text { exit }\end{array}$ & 433 & $\frac{460-620}{541.3 \pm 37.99}$ & $\frac{420-508}{458.0 \pm 20.04}$ & 4 & $\frac{450-696}{564.5 \pm 24.5}$ \\
\hline $\begin{array}{l}\text { Circumference at the base of } \\
\text { the alveolar part }\end{array}$ & 182 & $\frac{171-231}{196.3 \pm 18.93}$ & $\frac{166-198}{182.7 \pm 4.01}$ & 3 & $\frac{162-223}{188.9 \pm 7.3}$ \\
\hline $\begin{array}{l}\text { Circumference at the exit } \\
\text { from the alveolus }\end{array}$ & 184 & $\frac{185-236}{207.5 \pm 15.75}$ & $\frac{182-207}{198.8 \pm 6.17}$ & 5 & $\frac{188-255}{208.0 \pm 6.28}$ \\
\hline $\begin{array}{l}\text { Anterior-posterior diameter } \\
\text { at the base of the alveolar } \\
\text { part }\end{array}$ & 64.6 & $\frac{60-72}{68.5 \pm 14.08}$ & $\frac{59.5-73.3}{66.1 \pm 6.56}$ & 4 & $\frac{58-81}{68.57 \pm 2.48}$ \\
\hline $\begin{array}{l}\text { The transverse diameter at } \\
\text { the base of the alveolar part }\end{array}$ & 47.2 & $\frac{41.2-53}{47.3 \pm 13.0}$ & $\frac{39.4-47.4}{44.5 \pm 6.24}$ & 4 & $\frac{36-55.5}{43.91 \pm 2.1}$ \\
\hline $\begin{array}{l}\text { Anterior-posterior diameter } \\
\text { at the exit from the alveolus }\end{array}$ & 67.7 & $77.7 \pm 12.21$ & $\frac{66.5-77.4}{70.9 \pm 6.0}$ & 4 & $\frac{69-91.7}{75.59 \pm 2.21}$ \\
\hline $\begin{array}{l}\text { Transverse diameter at the } \\
\text { exit from the alveolus }\end{array}$ & 45.7 & $\frac{48.6-55}{51.6 \pm 11.6}$ & $\frac{46.6-50.6}{49.1 \pm 5.72}$ & 4 & $\frac{42.4-58.5}{49.84 \pm 1.78}$ \\
\hline $\begin{array}{l}\text { The minimal depth of the } \\
\text { tusk alveolus }\end{array}$ & 25 & $\underline{34-48}$ & $\frac{29-35}{32.0 \pm 6.36}$ & 3 & $\frac{23-42}{33.4 \pm 1.77}$ \\
\hline $\begin{array}{l}\text { The maximal depth of the } \\
\text { tusk alveolus }\end{array}$ & 38 & $\frac{38-56}{47.5 \pm 10.68}$ & $\frac{36-58}{46.0 \pm 6.15}$ & 3 & $\frac{32-112}{52.7 \pm 6.93}$ \\
\hline $\begin{array}{l}\text { Length of the alveolar part } \\
\text { of the tusk }\end{array}$ & 170 & $\frac{158-186}{173.8 \pm 10.32}$ & $\frac{180-195}{185.7 \pm 5.96}$ & 3 & $\frac{185-225}{196.0 \pm 3.99}$ \\
\hline
\end{tabular}

hundreds of skulls have been found in the North Sea, sometimes even completely intact, dating between 50,000 and 23,500 years (Aaris-Sorensen et al., 1990; Post, 1999). This indicates a long period of walrus presence in the North Sea, probably intermittently (Mol et al., 2003). It is likely that global climatic changes during the Late Pleistocene made the species move further south, closer to Atlantic Ocean and Pacific Ocean (Mol et al., 2003).

Following the glaciation, walrus appeared in the area of the Arctic Archipelago (Harington, 2008). Radiocarbon dates prove a nearly continuous walrus inhabitation of the East Canada Atlantic Coast from 12,800 years ago to the modern age (Harington, 2003).

After flooding of the shelf zone, solid ice cover destruction and disappearance of the land bridge be- tween Asia and North America in the Holocene, walrus quickly inhabited the coastal waters of Yakutia (Boeskorov \& Baryshnikov, 2013). In the early Holocene (about $9,000-8,000$ years ago) the walrus was present near the Zhokhov Island with its bone remains found there in a Mesolithic site (Pitulko \& Kasparov, 1996) (Fig. 5). The finds on Zhokhov include many reindeer (Rangifer tarandus (Linnaeus, 1758)) and polar bear bone remains, as they presumably were prey for inhabitants of the site, which was a hunting camp. A small number of seal (Phocidae gen. et sp. indet.) fossils was also found at this site. It seems that humans were hunting marine mammals like walrus and seal or simply taking the ones who were driven ashore (Pitulko, 1998; Pitulko \& Kasparov, 1996). The two Late Neolithic sites $(4,000$ 3,000 years old) Ularovskaya and Tatyanino, located in 


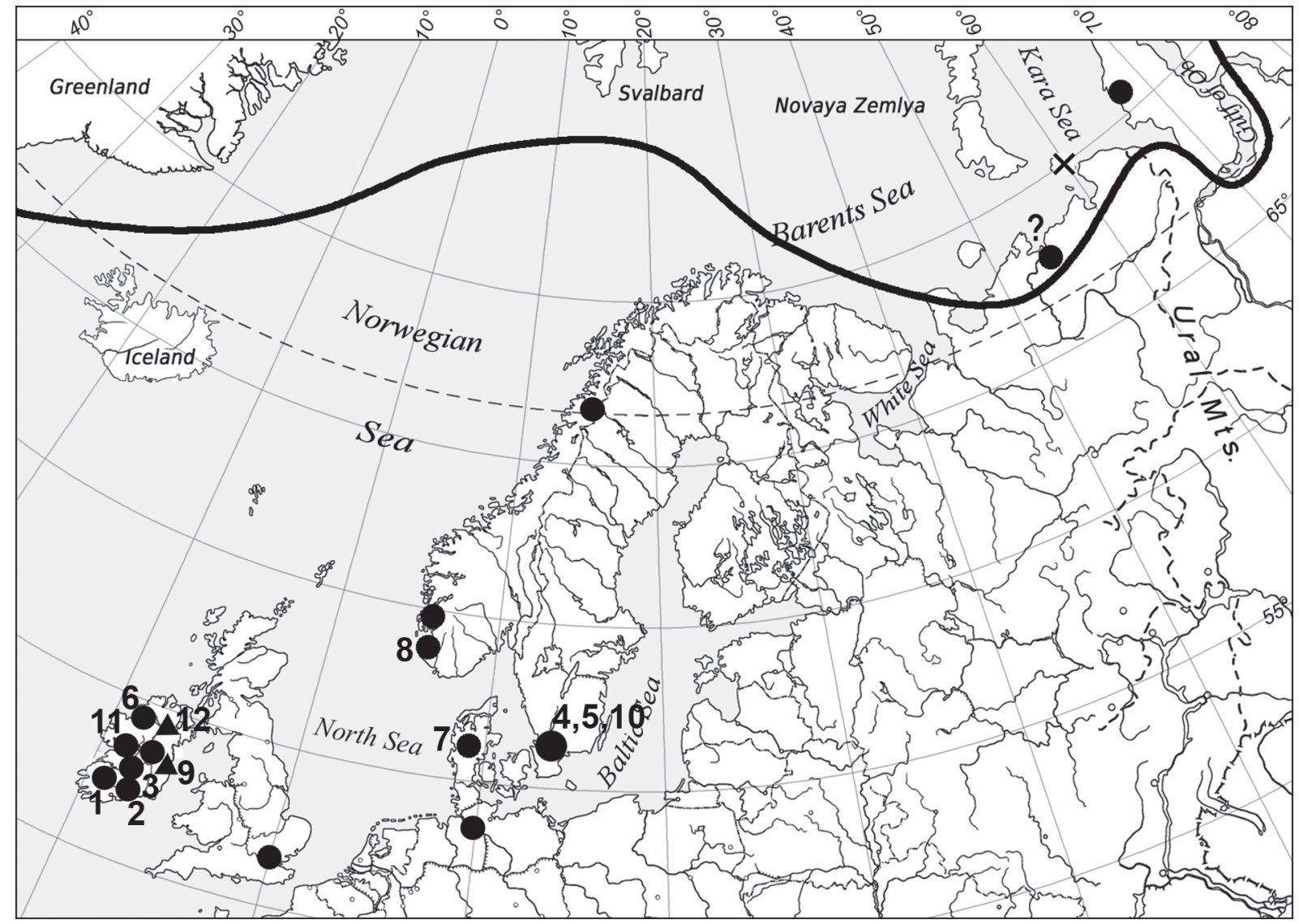

Fig. 4. Late Pleistocene (black circles) and Holocene (black triangles) fossil finds of a polar bear (Ursus maritimus) in Europe (except Svalbard). Numbering of radiocarbon dated finds is according to Tab. 4. The cross indicates a find on Vaigach Island; the continuous line is the southern boundary of the modern distribution of polar bears.

Table 4. Late Pleistocene and Holocene finds of polar bear (Ursus maritimus) remains in Europe.

\begin{tabular}{|c|c|c|c|}
\hline No. (*) & Locality & Radiocarbon date (BP) & Source \\
\hline & \multicolumn{3}{|c|}{ Late Pleistocene } \\
\hline 1 & Castlepook Cave, Cork, Ireland & $32,648-37,870$ & Edwards et al., 2011 \\
\hline 2 & Shandon Cave, Waterford, Ireland & $28,390-32430$ & Edwards et al., 2011 \\
\hline 3 & Foley Cave, Cork, Ireland & $26,340 \pm 320$ & Edwards et al., 2011 \\
\hline 4 & Kullaberg, Scania, Sweden & $\begin{array}{l}12,320 \pm 125 \\
12,480 \pm 185\end{array}$ & Berglund et al., 1992 \\
\hline 5 & Östra Karup, Scania, Sweden & $12,230 \pm 130$ & Berglund et al., 1992 \\
\hline 6 & Kesh Corran, Sligo, Ireland & $11,920 \pm 85$ & Edwards et al., 2011 \\
\hline 7 & Asdal, Jutland, Denmark & $\begin{array}{l}11,100 \pm 160 \\
11,240 \pm 180\end{array}$ & $\begin{array}{l}\text { Aaris-Sørensen, Petersen, } \\
\text { 1984; Kurtén, } 1988\end{array}$ \\
\hline 8 & Finnøy, Norway & $10,925 \pm 110$ & Blystad et al., 1983 \\
\hline 9 & Red Cellar Cave, Limerick, Ireland & $10,650 \pm 100$ & Edwards et al., 2011 \\
\hline 10 & Kürod, Bohuslän, Sweden & $10,430-10,620$ & $\begin{array}{l}\text { Håkansson, 1976; Kurtén, } \\
1988\end{array}$ \\
\hline \multirow[t]{2}{*}{11} & Edenvale Cave, Clare, Ireland & $10,495 \pm 51$ & Edwards et al., 2011 \\
\hline & \multicolumn{3}{|c|}{ Holocene } \\
\hline 11 & Edenvale Cave, Clare, Ireland & $9,946 \pm 53$ & Edwards et al., 2011 \\
\hline \multirow[t]{2}{*}{9} & Red Cellar Cave, Limerick, Ireland & $8719 \pm 48$ & Edwards et al., 2011 \\
\hline & Svenskøya, Svalbard, Norway & $7,760 \pm 50$ & Ingolfsson \& Wiig, 2008 \\
\hline \multirow[t]{2}{*}{12} & Poll nam Béar Cave, Leitrim, Ireland & $2,956-4,520$ & Edwards et al., 2011 \\
\hline & Vaygach Island, Russia & $1,971 \pm 25$ & this work (OxA-23631) \\
\hline
\end{tabular}

The Pleistocene/Holocene boundary is taken as 11,650 calBP which (in ${ }^{14} \mathrm{C}$ years) corresponds to ca. 10,200 BP (Reimer et al., 2013).

$(*)$ numbers correspond to those in Fig. 4. 


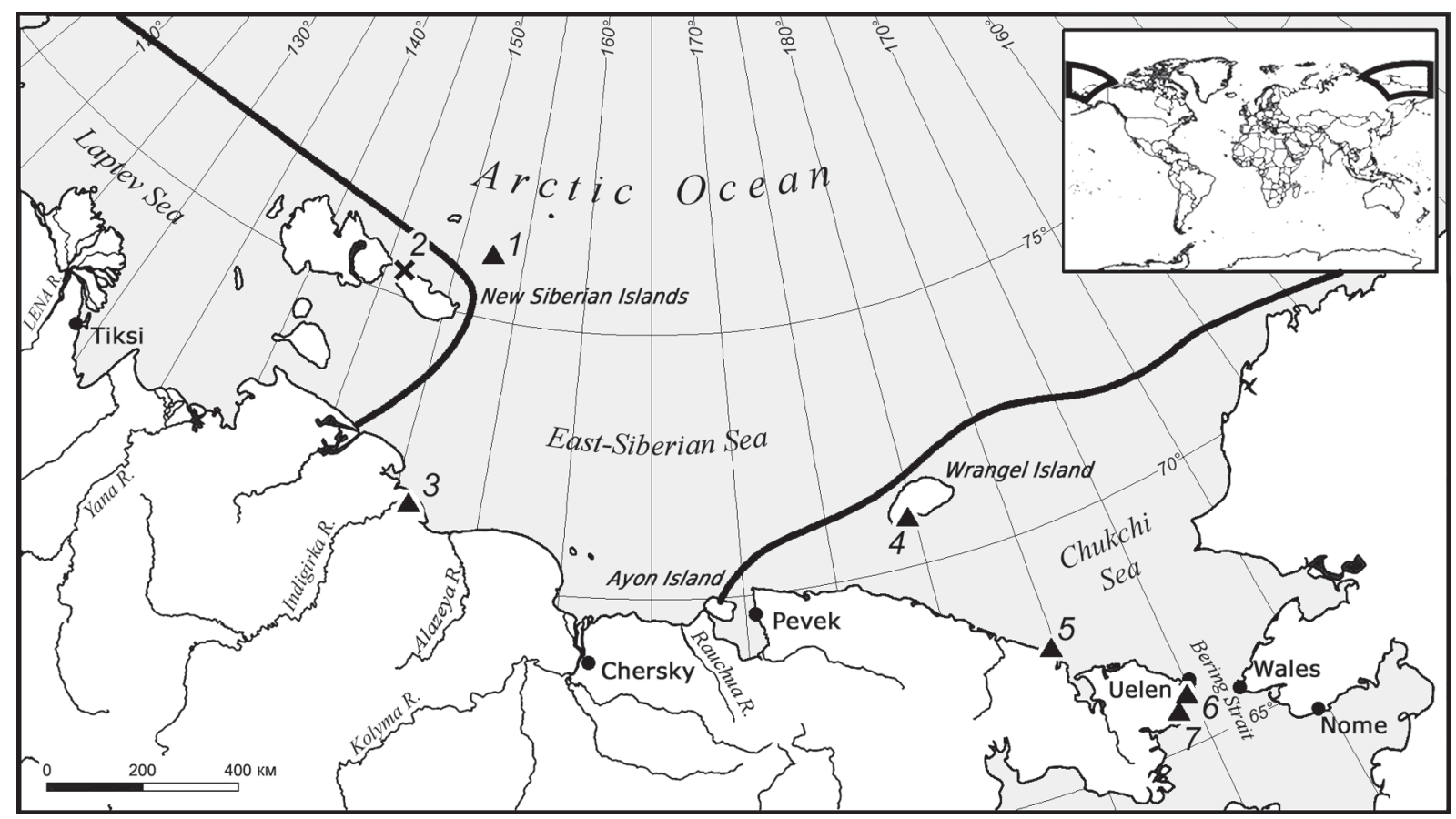

Fig. 5. Holocene (black triangles) walrus find (Odobenus rosmarus) in the Arctic zone of Siberia. The cross indicates a find on the New Siberia Island; the continuous line is the northern boundary of the modern spread of the walrus. Numbering of finds is according to Tab. 3 .

the Indigirka River delta about $25 \mathrm{~km}$ apart, yielded valuable finds of different walrus bones (Okladnikov \& Gurvich, 1957). The "Spearhead (or arrow-head) made from walrus tusk" mentioned above was found at the Tatyanino Lake settlement. Based on these finds A.P. Okladnikov presumed that inhabitants of Tatyanino Lake were "hunters on marine animals" (Okladnikov, 1955: 123). Fedoseeva (1980) believed that Ularovskaya and Tatyanino sites belonged to the Ymyyakhtakh culture, which was widely spread throughout the Yakutia territory during the Late Neolithic. Fedoseeva (1980: 209) did not rule out the possibility that Ymyyakhtakh people preyed on "...some kinds of pinnipeds that traveled several dozen kilometers from the sea up the rivers". Finds from the Indigirka River are known to be outside of the modern walrus species range (Fig. 5).

A walrus bone from the Chertov Ovrag (Devil's Gorge) settlement on the south end of Wrangel Island is nearly the same age (Gerassimov et al., 2004) (Tab. 4, Fig. 5). Later finds are from ancient Eskimo settlements on Chukotka Peninsula. Radiocarbon dates suggest that inhabitants of these settlements were hunting walruses since 2,700 years ago (Knyazev, 1995).

Archaeological excavations of the Medieval Eskimo settlement on Chetyrekhstolbovoy Island by Y.A. Mochanov provided some pinniped fossils, but not a single walrus bone was found there (Boeskorov \& Baryshnikov, 2013). It is likely that in medieval times walruses were not living permanently in the central areas of the East Siberian Sea.
Mitochondrial DNA analysis showed that Laptev Sea subspecies O. rosmarus laptevi and Pacific Ocean walrus subspecies $O . r$. divergens (Illiger, 1815) are similar in many ways, which led us to believe that walrus expansion in the Yakutia Arctic waters took place from the east, to be more specific, from the Pacific Ocean regions (Lindqvist et al., 2009).

It is known that in the early Holocene the sea level of the Laptev Sea and East Siberian Sea were 20-25 meters lower than today. Consequently, the larger part of the New Siberian Islands, including Vilkitsky Island, Zhokhov Island, and New Siberia Island, were connected to the Siberian mainland (Andreev et al., 2008; Pitulko, 1998; Pitulko \& Kasparov, 1996). A Radiocarbon date 3,940 \pm 40 (LU-2518) of driftwood found at higher parts of the laida (low-lying seashore with flooded meadows) (2.5-3 meters high) on Zhokhov Island shows that the ocean level reached its peak about 4,0004,500 years ago. It was assumed that by this time, or perhaps a bit earlier (5,000-6,000 years ago), the New Siberian Islands Archipelago was separated from the mainland (Makeev et al., 1992). The ca. 5,000 years old walrus tusk find from the New Siberia Island can be considered a proof of the theory that the coastline of New Siberian Islands as we know it today was formed during the Middle Holocene.

Acknowledgments. The authors thank Ms. Anna A. Tikhonova for translation text of the manuscript into English. We are grateful to Dr. A.B. Savinetsky (A.N. 
Severtsov Institute of Ecology and Evolution, RAS, Moscow) and Dr. V.V. Pitulko (Institute of the History of Material Culture, RAS) for the discussing material of the article.

The study was fulfilled within a framework of the Federal theme of the Laboratory of Theriology ZIN RAS No. AAAA-A17-117022810195-3 "Phylogeny, morphology and systematics of placental mammals" and the Program of the Russian Academy of Sciences Presidium "Evolution of the organic world. The role and significance of planetary processes" using the collection of ZIN RAS, and within the framework of the Ministry of Education and Science of Russia state task no. 37.7935.2017 / 6.7.

\section{References}

Aaris-Sørensen K. \& Petersen K.S. 1984. A Late Weichselian find of a polar bear (Ursus maritimus) from Denmark and reflections on the paleoenvironment // Boreas. Vol.13. P.29-33.

Aaris-Sørensen K., Petersen K.S. \& Tauber H. 1990. Danish Finds of Mammoth (Mammuthus primigenius (Blumenbach)). Stratigraphical position, dating and evidence of Late Pleistocene environment // Danmarks Geologiske Untersøgelse. Serie B. Vol.14. P.1-44.

Allen J.A. 1880. History of North American pinnipeds, a monograph of the walruses, sea-lions, sea-bears and seals of North America // U.S. Geol. Geogr. Surv. Ter. Misc. Publ. N.12. P.1-785.

Andreev A.A., Grosse G., Schirrmeister L., Kuznetsova T.V., Duzmina S.A., Bobrov A.A., Tarasov P.E., Novenko E.Y., Meyer H., Derevyagin A.Y., Kienast F., Bryantseva A. \& Kunitsky V.V. 2008. Weischelian and Holocene palaeoenvironmental history of the Bol'shoy Lyakhovsky Island, New Siberian Archipelago, Arctic Siberia // Boreas. Vol.38. P.72-110.

Aristov A.A. \& Baryshnikov G.F. 2001. [The Mammals of Russia and adjacent territories. Carnivores and Pinnipeds]. Saint-Petersburg: Izdatel'stvo SPbGU. 560 p. [In Russian]

Arutyunov S.A. \& Sergeev D.A. 1975. [Problems of the ethnic history of the ancient Bering Sea region (an Ekven burial ground)]. Moscow: Nauka. 240 p. [In Russian]

Baryshnikov G.F. 2007. [Bear Family (Carnivora, Ursidae) // Fauna Rossii. Mlekopitayushchie. Vol.1. Vyp.5. SaintPetersburg: Nauka. 541 p. [In Russian]

Berglund B.E., Håkansson S. \& Lepiksaar J. 1992. Late Weichselian polar bear (Ursus maritimus Phipps) in southern Sweden // Sveriges Geologiska Undersökning. Series Ca. Vol.81. P.31-42.

Blystad P., Thomsen H., Simonsen A. \& Lie R.W. 1983. Find of a nearly complete Late Weichselian polar bear skeleton, Ursus maritimus Phipps, at Finnøy, southwestern Norway: a preliminary report // Norsk Geologisk Tidskrift. Vol.63. P.193-197.

Boeskorov G.G. \& Baryshnikov G.F. 2013. [Late Quaternary Carnivora of Yakutia]. Saint-Petersburg: Izdatel'stvo Nauka. 199 p. [In Russian]

Chapsky K.K. 1963. [Walruses]. Mlekopitayushchiye fauny SSSR. Vol. 2. Moscow-Leningrad: Izdatel'stvo Akademii Nauk SSSR. P.915-920 [in Russian].
Crockford S.J. 2012. Annotated Map of Ancient Polar Bear Remains of the World. Electronic resource available at http://polarbearscience/references/

Dikov N.N. 1974. [Chukotka in the Stone Age] // Dikov N.N. (ed.). Ocherki istorii Chukotki s drevneyshikh vremen do nashikh dney. Novosibirsk: Nauka. P.18-45 [in Russian].

Dikov N.N. 1977. [Archaelogical sites of the Kamtchatka, Chukotka and Upper Kolyma]. Moscow: Izdatel'stvo Nauka. 391 p. [In Russian]

Dinesman L.G., Kiseleva N.K., Savinetsky A.B. \& Khasanov B.F. 1996. [The age-old dynamics of the near-cost ecosystems of the Northeast Chukotka]. Moscow: Argus. 186 p. [In Russian]

Driesch A., von den. 1976. A guide to the measurement of animal bones from archaeological sites // Peabody Museum Bulletin. Vol.1. P.1-136.

Edwards C.J., Suchard M.A., Lemey Ph., Welch J.J., Barnes I., Fulton T.L., Barnett R., O'Connell T.C., Coxon P., Monaghan N., Valdiosera C.E., Lorenzen E.D., Willerslev E., Baryshnikov G.F., Rambaut A., Thomas M.G., Bradley D.J. \& Shapiro B. 2011. Ancient hybridization and an Irish origin for the modern polar bear matriline // Current Biology. Vol.21. P.1251-1258.

Erdbrink D.P. 1953. A review of fossil and recent bears of the Old World, with remarks on their phylogeny based upon their dentition. Deventer: Drukkerij Jan de Lange. $597 \mathrm{p}$.

Fedorova N.V., Kosintsev P.A. \& Fitzhugh V.V. 1998. [Gone into the hills]. Yekaterinburg: "Yekaterinburg". $132 \mathrm{p}$. [In Russian]

Fedoseeva S.A. 1980. [Ymyyakhtakh culture of Northeast Asia]. Novosibirsk: Izdatel'stvo Nauka. 224 p. [in Russian]

Gerassimov D.V., Girya E.Yu. \& Tikhonov A.N. 2004. [Settlement of the Chertov Ovrag on the Wrangel Island Cultural Attributions and Prospects for Research] // Nikolsky P.A. \& Pitulko V.V. (eds.). Yestestvennaya istoriya rossiyskoy vostochnoy Arktiki v pleystotsene i golotsene. Moscow: GEOS. P.85-88 [in Russian].

Gorlova E.N. \& Vasyukov D.D. 2013. Three species of Pinnipeds in hunting gain of sea hunters at the northwestern coast of Chukchi Peninsula // Zoologicheskii Zhurnal. Vol.92. No.9. P.1064-1076 [in Russian].

Gromova V.I. 1950. [The Guide of the USSR mammals on bones of a skeleton. The Guide for large bones] // Trudy Komissii po izucheniyu chetvertichnogo perioda. Vol.9. No.1. P.1-240 [in Russian].

Håkansson S. 1976. University of Lund radiocarbon dates. IX // Radiocarbone. Vol.18. No.3 P.290-320.

Harington C.R. 2003. Annotated Bibliography of Quaternary Vertebrates of Northern North America with radiocarbon dates. Toronto: University of Toronto Press. 539 p.

Harington C.R. 2008. The evolution Arctic marine mammals // Ecological Applications. Vol.18. No.2. Supplement. P. 23-40.

Harington C.R. \& Beard G. 1992. The Qualicum walrus: a Late Pleistocene walrus (Odobenus rosmarus) skeleton from Vancouver Island, British Columbia, Canada // Annales Zoologici Fennici. Vol.28. P.311-319. 
Heptner V.G., Chapsky K.K., Arsen'ev V.A. \& Sokolov V.E. 1976. [Mammals of the Soviet Union]. Vol.2. Part 3. Pinnipeds and toothed whales. Moscow: Vysshaya shkola. 718 p. [In Russian]

Ingólfsson Ó. \& Wiig Ø. 2008. Late Pleistocene fossil find in Svalbard: the oldest remains of a polar bear (Ursus maritimus Phipps, 1744) ever discovered // Polar Research. Vol.28. P.455-462.

Knyazev A.V. 1995. [The hunting game of the ancient Eskimos of the Bering Strait] // Byulleten' moskovskogo obshchestva ispytateley prirody. Otdelenie Biologii. Vol.100. No.2. P.22-33 [in Russian].

Kosintsev P.A. 2006. [Ecology of the West Siberia Human Medieval population]. Yekaterinburg-Salekhard: Uralskii Universitet. 272 p. [In Russian]

Kurtén B. 1964. The evolution of the polar bear, Ursus maritimus Phipps // Acta Zoologica Fennica. N.108. P.1-30.

Kurtén B. 1988. On Evolution and Fossil Mammals. New York: Columbia University Press. 301 p.

Lindqvist C., Bachmann L., Andersen L.W., Born E.W., Arnason U., Kovacs K.M., Lydersen C., Abramov A.V. \& Wiig Ø. 2009. The Laptev Sea walrus Odobenus rosmarus laptevi: an enigma revisited // Zoologica Scripta. Vol.38. P.113-127.

Makeev V.M., Pitulko V.V. \& Kasparov A.K. 1992. [The natural environment of the De-Long archipelago at the end of the Pleistocene - the beginning of the Holocene and the Ancient Man] // Izvestia Russkogo Geographicheskogo Obshchestva. Vol.124. No.3. P.271-276 [in Russian].

Mochanov Yu.A. 1977. [The earliest stages of the human settlement of the Northeast Asia]. Novosibirsk: Nauka. 246 p. [In Russian]

Mol D., Post K., Reumer J., van der Plicht J. \& De Vos J. 2003. Late Pleistocene terrestrial and marine mammals from the Eurogeul, North Sea, The Netherlands // Occasional Papers in Earth Sciences. No.5. P.92-97.

Mook W.G. \& van der Plicht J. 1999. Reporting ${ }^{14} \mathrm{C}$ activities ad concentrations // Radiocarbon. Vol.41. P.227-239.

Morlan R.E. 1999. Canadian Archaeological radiocarbon database. Electronic resource available at http:// canadianarchaeology.com/radiocarbon/card/card.htm

Ognev S.I. 1935. [Mammals of the USSR and adjacent territories. Pinnipeds]. Moscow-Leningrad: Biomedgiz. Vol.3. P.322-600 [in Russian]

Okladnikov A.P. 1955. [History of the Yakutian ASSR]. Moscow-Leningrad: Akademiya nauk SSSR. Vol.1. 432 p. [In Russian]

Okladnikov A.P. \& Gurvich I.S. 1957. [Ancient settlements in the Indigirka river delta] // Kratkiye soobshcheniya Instituta arkheologii. Vol. 27. P. 42-51 [in Russian].
Pitulko V.V. 1998. [The Zhokhov site]. Saint-Petersburg: Dmitry Bulavin. 185 p. [In Russian]

Pitulko V. \& Kasparov A. 1996. Ancient Arctic hunters: material culture and survival strategy // Arctic Anthropology. Vol.33. P.1-36.

Pitulko V.V. \& Pavlova E.Yu. 2010. [Geoarcheology and radiocarbon chronology of the Stone Age of North-East Asia]. Saint-Petersburg: Nauka. 264 p. [In Russian]

Post K. 1999. Laat Pleistocene zeezoogdieren van de Nederlandse kustwateren // Grondboor \& Hamer. Vol.53. No.6. P.126-130 [in Dutch].

Reimer P.J., Bard E., Bayliss A., Beck J.W., Blackwell P.G., Bronk Ramsey C., Buck C.E., Cheng H., Edwards R.L., Friedrich M., Grootes P.M., Guilderson T.P., Haflidason H., Hajdas I., Hatté C., Heaton T.J., Hoffmann D.L., Hogg A.G., Hughen K.A., Kaiser K.F., Kromer B., Manning S.W., Niu M., Reimer R.W., Richards D.A., Scott E.M., Southon J.R., Staff R.A., Turney C.S.M. \& van der Plicht J. 2013. IntCal13 and Marine13 radiocarbon age calibration curves, 0-50,000 years cal BP // Radiocarbon. Vol.55. P.1869-1887.

Semenov S.A. 1957. [Primitive technology]. Moscow-Leningrad: AN SSSR Publ. 240 p. [In Russian]

Sokolov V.E. 2001. [Systematics and taxonomy] // Pavlov D.S. \& Bychkov V.A. (eds.). Morzh: obraz vida. Moscow: Nauka. P.8-11 [in Russian].

Tauber H. 1979. 14C-dating of arctic marine mammals. // Berger R. \& Suess H.E. (eds.). Radiocarbon dating. Berkeley/Los Angeles: University of California Press. P.447-452.

Tishkov V.A., Zhuravsky A.V. \& Kaz'mina O.E. 2008. [Peoples of Russia: An Atlas of the cultures and religions]. Moscow: Feeria. 320 p. [In Russian]

Uspensky S.M. \& Kholodova M.V. 1977. [Craniological materials on the polar bear from the Nenets people sacrificial altars] // Uspensky S.M. (ed.). Belyi medved' i yego okhrana v Sov'etskoy Arktike. Moscow: Izdatel'stvo VNIISHT. P. 86-97 [in Russian].

Vereshchagin N.K. 1969. [The origin and evolution of the polar bear] // Bannikov A.G. (ed.). Belyy medved' i yego okhrana v Sovetskoy Arktike. Leningrad: Gidrometeoizdat. P.25-53 [in Russian].

Vereshchagin N.K. \& Tikhonov A.N. 1987. [Study of mammoth tusks from the permafrost of the North-East of Siberia] // Zoologicheskii Zhurnal. Vol.66. N.4. P.632634 [in Russian].

Zimmermann K.G. 1845. Über einige in der Lilienstraße in Hamburg gefundene Schädel und Knochen // Neues Jahrbuch für Mineralogie, Geognosie, Geologie und Paläontologie. S.73-74. 